\title{
Improved Quantification of Glomerular Filtration Rate and Differential Renal Function of Ectopic Kidneys in a Dual Head Gamma Camera
}

\author{
Gopal Sonai Muthu*, Sujata Mitra \\ Department of Nuclear Medicine \& Immunoassay, Tata Main Hospital, Jamshedpur, India \\ Email: "gopalsonaimuthu@gmail.com
}

Received 23 December 2013; revised 23 January 2014; accepted 30 January 2014

Copyright (C) 2014 by authors and Scientific Research Publishing Inc. This work is licensed under the Creative Commons Attribution International License (CC BY). http://creativecommons.org/licenses/by/4.0/

(c) (i) Open Access

\begin{abstract}
Introduction: Tc-99m Di-ethylene Tri-amine Penta Acetic Acid (DTPA) renogram is an accepted method to measure Glomerular Filtration Rate (GFR) of the kidneys. The depth and position of ectopic kidneys may vary. This may lead to variation in tissue attenuation and error in the computed GFR and Differential Renal Function (DRF) of each kidney. Objective: The present study was undertaken in patients with ectopic kidneys to improve the accuracy of GFR and DRF calculation in a renogram with single injection of Tc-99m DTPA on a dual head gamma camera. Materials and Method: The study was conducted on 55 patients with ectopic kidneys. Images were acquired on a dual head gamma camera simultaneously in anterior and posterior views. Both anterior and posterior image datasets were used to compute the GFR of the ectopic kidney by Gates method. Depth correction of the ectopic kidney was done using the lateral view image. Total GFR was calculated as the sum of the anterior dataset ectopic kidney GFR and the posterior dataset normal kidney GFR. DRF was calculated again, by using the anterior dataset GFR of the ectopic kidney and posterior dataset for normal kidneys. The total GFR calculated by our method was compared to the patient's eGFR (based on serum creatinine, age and sex). Result: The GFR calculated by anterior data set in the ectopic kidney was significantly higher than that calculated by posterior dataset $(p<$ 0.001). Similarly, the differential GFR of the ectopic kidney was higher when the anterior dataset was used $(p<0.001)$. The ectopic kidney GFR of $34(61.8 \%)$ of the 55 patients was greater than 35 $\mathrm{ml} / \mathrm{min}$, whereas in 21 patients $(38.2 \%)$, it was less than $35 \mathrm{ml} / \mathrm{min}$. The total GFR calculated by using both anterior and posterior data set was compared with the eGFR; the correlation coefficient was 0.74 in patients with ectopic kidney GFR of $>35 \mathrm{ml} / \mathrm{min}$ and 0.83 in those with $<35 \mathrm{ml} / \mathrm{min}$. Conclusion: The GFR of ectopic kidney as calculated from the anterior data set was significantly higher in comparison to the GFR calculated from the posterior data set $(p<0.001)$. Using the ante-
\end{abstract}

\footnotetext{
${ }^{*}$ Corresponding author.
} 
rior dataset GFR, the DRF values for the ectopic kidneys was also significantly higher $(p<0.001)$. This method improves the accuracy of the GFR and DRF values and helps to differentiate a normally functioning ectopic kidney from a poorly functioning one. Compared to the total GFR as calculated by the present method, the eGFR showed a better correlation in patients with ectopic kidney GFR $<35.0 \mathrm{ml} / \mathrm{min}$.

\section{Keywords}

Ectopic Kidney; Glomerular Filtration Rate; Differential Renal Function

\section{Introduction}

DTPA renal scintigraphy is used in assessing the functional status of the kidneys by injecting Tc-99m DTPA and acquiring a dynamic study. Tc-99m DTPA is filtered by the glomerulus with almost no tubular secretion or re-absorption. Conventionally the renal dynamic study is done with patient in the supine position and the camera detector posterior to the patient. Post-acquisition processing is done with the posterior image data set to generate renogram curves and to compute the GFR, DRF and other quantitative parameters. The depth and position of an ectopic kidney can vary and they are usually anterior to the normally positioned kidney. This leads to an underestimation of the quantitative parameters of the ectopic kidneys from the posterior renogram [1]. This study has acquired and processed renogram data in a dual head gamma camera in anterior and posterior views simultaneously and used modified computational methods to improve the accuracy of GFR and DRF estimation in patients with ectopic kidney. GFR of the ectopic kidney has been computed by Gates method with depth correction from the anterior renogram. GFR of the normal kidney has been computed by Gates method from posterior renogram. DRF of the ectopic and normal kidney has been computed using the formulae shown in Equations (1) and (2). Changes in the GFR and DRF values of the ectopic kidneys and the total GFR in this method are analyzed.

\section{Materials and Method}

The study included 55 serial patients with ectopic kidneys referred for a DTPA renogram from January 2007 to December 2012. There were 38 males with a mean age of 40.9 years (range: 7 to 74 years) and 17 females with a mean age of 36.8 years (range: 18 to 64 years). Of the 38 males, 25 had ectopic left kidney and 10 had ectopic right kidney. Of the 17 females7 had ectopic left kidney and nine had ectopic right kidney. Patients with suspected ectopic kidney, crossed fused ectopia and solitary pelvic kidney diagnosed on ultrasound were included in this study. Patients with horse shoe kidney and posteriorly positioned thoracic kidney were excluded.

Renal scintigraphy was performed on a GE Millennium MG dual head gamma camera (Model number H3000ZL, serial Number 51,432, manufacturing date $17^{\text {th }}$ October 2006) with a Genieac image acquisition system and a Xeleris post processing workstation. Patient preparation included adequate hydration. Patients were imaged in the supine position with both camera detectors positioned close to the patient including the kidneys and bladder in the field of view [2]-[4]. A bolus dose (approximately $0.1 \mathrm{mCi}$ per kg bodyweight) between 5 and $10 \mathrm{mCi}(185$ and $370 \mathrm{MBq}$ ) of Tc-99m DTPA was administered intravenously. Images were acquired simultaneously both by the anterior and posterior detectors in the following time frames: 2 seconds per frame for the first one minute, 30 second per frame for the next four minutes and 60 seconds per frame for the rest of the study. Data was acquired for 20 minutes [4].

Thus, two sets of images were acquired simultaneously in anterior and posterior views in Genieacq acquisition system with single injection of Tc-99m DTPA. A protocol was developed to process the renogram data sets obtained from the anterior detector. GFR values were computed in Xeleris workstation using the Gate's technique [5]. Renogram analyses were done separately for the two data sets, anterior and posterior.GFR of the ectopic kidney was computed from the anterior data set images by entering the depth of the ectopic kidney measured from the post void lateral images [6]-[8]. GFR of the normal kidney was calculated by the posterior dataset. The GFR of the normal and ectopic kidney were noted down from the posterior and the anterior datasets respectively. Equations (1) and (2) were used to compute the DRF (this method could also be applied if anterior and 
posterior datasets are acquired separately, as in single head gamma camera).

$$
\begin{aligned}
\text { DRF NK } & =\frac{\text { GFR NK }}{\text { GFR NK }+ \text { GFR EK }} \\
\text { DRF EK } & =\frac{\text { GFR EK }}{\text { GFR NK + GFR EK }}
\end{aligned}
$$

DRF NK = Differential Renal Function of the normal kidney, DRF EK = Differential Renal Function of the ectopic kidney, GFR NK = GFR of the normal kidney from posterior data set and GFR EK = GFR of the ectopic kidney from anterior data set.

Significance in the increase of GFR and DRF values was analyzed using Student's t test and a p value less than 0.05 was considered statistically significant.

DRF was also computed from the geometric mean of the dataset obtained from anterior and posterior views in the Xerleris workstation [9]-[13]. However this method would require simultaneous acquisition of anterior and posterior images.

A GFR value greater than $35 \mathrm{ml} / \mathrm{min}$ as calculated from anterior data set was considered normal for the ectopic kidney (in patients with normal creatinine clearance rate, a total GFR greater than $70 \mathrm{ml} / \mathrm{min}$ is considered normal renal functional status for a kidney donor [14] [15]. Difference in absolute GFR (total GFR and ectopic kidney GFR) and DRF as calculated from the anterior data set was analyzed in the following two groups: 1) patients with ectopic kidney GFR greater than $35 \mathrm{ml} / \mathrm{min}$ and 2) patients with ectopic kidney GFR less than 35 $\mathrm{ml} / \mathrm{min}$. A comparison was made between the total GFR calculated by this method and the eGFR calculated by Cockcroft Gault method in both groups of patients [16].

\section{Result}

Absolute and percent increase in GFR of ectopic kidney, absolute and percent increase in the total GFR and percent increase in DRF of ectopic kidney as calculated from anterior renogram dataset are summarized in Table 1 .

GFR of ectopic kidneys calculated by anterior dataset was significantly higher compared to that calculated by posterior dataset $(\mathrm{p}<0.002)$ in all patients. Of the 55 patients studied, $34(61.8 \%)$ showed ectopic kidney GFR greater than $35 \mathrm{ml} /$ minas calculated by anterior renogram (Table 2), and 21 patients (38.2\%) with values less than $35 \mathrm{ml} / \mathrm{min}$ (Table 3). Difference and the percent increase in DRF of the ectopic kidneys in these two groups of patients are shown in Tables 4 and 5 respectively.

Increase in absolute GFR and DRF values for patients with GFR of the ectopic kidney $>35 \mathrm{ml} / \mathrm{min}$ from anterior data set are summarized in Table 6. Increase in GFR in these patients (compared to posterior data set GFR calculation) was $24.4 \mathrm{ml} / \mathrm{min}(\mathrm{SD} \pm 6.4)$. Percentage increase in the GFR of the ectopic kidney showed a mean value of 144.0 ( $S D \pm 61.7$ ). Percentage increase in the total GFR showed a mean value of 37.8 (SD \pm 10.8 ). Increase in DRF showed a mean value of 19.5 (SD \pm 5.3 ). Percentage increase in the DRF showed a mean value of 74.9 (SD \pm 32.6 ). A correlation of 0.4 was observed when the total GFR computed by this method was compared with the eGFR in this group.

Increase in GFR and DRF values for patients with GFR of the ectopic kidney $<35 \mathrm{ml} / \mathrm{min}$ from anterior data set are summarized in Table 7. Increase in GFR in these patients (compared to posterior data set GFR calculation) was $15.0 \mathrm{ml} / \mathrm{min}(\mathrm{SD} \pm 5.0)$. Percentage increase in the GFR of the ectopic kidney showed a mean value of 191.7(SD \pm 100.0$)$. Percentage increase in the total GFR showed a mean value of 46.1 (SD \pm 18.9).Increase in

Table 1. Increase in GFR and DRF values for patients $(n=55)$ with ectopic kidney from anterior data set.

\begin{tabular}{cccccc}
\hline & $\begin{array}{c}\text { Increase in GFR of } \\
\text { ectopic kidney }\end{array}$ & $\begin{array}{c}\text { \% Increase in GFR of } \\
\text { ectopic kidney }\end{array}$ & \% Increase in Total GFR & Increase in DRF & \% Increase in DRF \\
\hline Mean & 20.8 & 162.2 & 41.2 & 20.8 & 90.9 \\
SD & 7.4 & 81.9 & 15.0 & 6.6 & 77.8 \\
Min & 5.0 & 38.7 & 13.4 & 8.0 & 20.5 \\
Max & 43.9 & 437.2 & 81.5 & 35.8 & 586.5 \\
p & $<0.001$ & $<0.001$ & 0.002 & $<0.001$ & $<0.001$ \\
\hline
\end{tabular}


Table 2. Increase in GFR of ectopic kidney and total GFR and its comparison with eGFR in ectopic kidneys with GFR greater than $35 \mathrm{ml} / \mathrm{min}$.

\begin{tabular}{|c|c|c|c|c|c|c|c|c|c|c|c|}
\hline Sl. No. & Age & Sex & $\begin{array}{l}\text { Ectopic } \\
\text { Kidney }\end{array}$ & $\begin{array}{l}\text { GFR of } \\
\text { ectopic } \\
\text { kidney from } \\
\text { posterior } \\
\text { dataset } \\
\text { (ml/min) }\end{array}$ & $\begin{array}{l}\text { GFR of } \\
\text { ectopic } \\
\text { kidney from } \\
\text { anterior } \\
\text { dataset } \\
\text { (ml/min) }\end{array}$ & $\begin{array}{c}\text { Difference } \\
\text { in GFR of } \\
\text { ectopic } \\
\text { kidney } \\
(\mathrm{ml} / \mathrm{min})\end{array}$ & $\begin{array}{c}\text { \% Increase } \\
\text { in GFR of } \\
\text { ectopic } \\
\text { kidney }\end{array}$ & $\begin{array}{l}\text { Total GFR } \\
\text { with GFR of } \\
\text { ectopic kidney } \\
\text { form posterior } \\
\text { dataset } \\
(\mathrm{ml} / \mathrm{min})\end{array}$ & $\begin{array}{l}\text { Total GFR } \\
\text { with GFR of } \\
\text { ectopic kidney } \\
\text { form anterior } \\
\text { dataset } \\
(\mathrm{ml} / \mathrm{min})\end{array}$ & $\begin{array}{l}\text { \%Increase in } \\
\text { total GFR with } \\
\text { GFR of ectopic } \\
\text { kidney form } \\
\text { anterior dataset }\end{array}$ & $\begin{array}{c}\text { eGFR } \\
\text { (ml/min) }\end{array}$ \\
\hline 1 & 22 & M & LK & 16.9 & 49.7 & 32.8 & 194.1 & 72.5 & 105.3 & 45.2 & 112.2 \\
\hline 2 & 34 & M & LK & 19.4 & 47.3 & 27.9 & 143.8 & 85.3 & 113.2 & 32.7 & 84.8 \\
\hline 3 & 40 & M & LK & 11.5 & 40.7 & 29.2 & 253.9 & 59.4 & 88.6 & 49.2 & 77.3 \\
\hline 4 & 58 & F & LK & 18.4 & 37.2 & 18.8 & 102.2 & 75.5 & 94.3 & 24.9 & 83.8 \\
\hline 5 & 35 & M & LK & 26.1 & 49.7 & 23.6 & 90.4 & 99.2 & 122.8 & 23.8 & 91.7 \\
\hline 6 & 17 & M & RK & 25.7 & 40.2 & 14.5 & 56.4 & 67.2 & 81.7 & 21.6 & 89.8 \\
\hline 7 & 33 & $\mathrm{~F}$ & RK & 11.5 & 42.3 & 30.8 & 267.8 & 58.8 & 89.6 & 52.4 & 128.5 \\
\hline 8 & 48 & M & LK & 14.5 & 39.7 & 25.2 & 173.8 & 52.1 & 77.3 & 48.4 & 99.3 \\
\hline 9 & 24 & F & LK & 16.2 & 36.9 & 20.7 & 127.8 & 51.4 & 72.1 & 40.3 & 79.8 \\
\hline 10 & 34 & M & LK & 30.5 & 46.1 & 15.6 & 51.1 & 72.6 & 88.2 & 21.5 & 72.1 \\
\hline 11 & 49 & M & LK & 15.2 & 38.3 & 23.1 & 152.0 & 51.5 & 74.6 & 44.9 & 87.4 \\
\hline 12 & 36 & M & LK & 25.6 & 49.1 & 23.5 & 91.8 & 68.2 & 91.7 & 34.5 & 78.4 \\
\hline 13 & 29 & F & LK & 16.2 & 37.4 & 21.2 & 130.9 & 52.7 & 73.9 & 40.2 & 95.3 \\
\hline 14 & 18 & F & LK & 14.2 & 39.2 & 25.0 & 176.1 & 56.5 & 81.5 & 44.2 & 69.4 \\
\hline 15 & 21 & F & LK & 13.6 & 38.6 & 25.0 & 183.8 & 61.1 & 86.1 & 40.9 & 104.6 \\
\hline 16 & 35 & F & RK & 24.3 & 43.1 & 18.8 & 77.4 & 67.6 & 86.4 & 27.8 & 74.6 \\
\hline 17 & 37 & M & RK & 22.2 & 43.2 & 21.0 & 94.6 & 61.1 & 82.1 & 34.4 & 82.5 \\
\hline 18 & 27 & F & RK & 17.1 & 46.7 & 29.6 & 173.1 & 61.8 & 91.4 & 47.9 & 103.2 \\
\hline 19 & 23 & $\mathrm{~F}$ & LK & 17.05 & 38.7 & 21.7 & 127.0 & 53.2 & 74.9 & 40.7 & 102.7 \\
\hline 20 & 42 & M & LK & 19.6 & 35.2 & 15.6 & 79.6 & 58.5 & 74.1 & 26.7 & 81.4 \\
\hline 21 & 19 & $\mathrm{M}$ & LK & 15.76 & 59.7 & 43.9 & 278.8 & 76.0 & 120.0 & 57.8 & 102.1 \\
\hline 22 & 7 & M & LK & 35.4 & 49.1 & 13.7 & 38.7 & 90.8 & 104.5 & 15.1 & 80.9 \\
\hline 23 & 32 & F & RK & 11.3 & 38.7 & 27.4 & 242.5 & 50.8 & 78.2 & 53.9 & 116.9 \\
\hline 24 & 25 & F & RK & 17 & 43.7 & 26.7 & 157.1 & 61.7 & 88.4 & 43.3 & 89.9 \\
\hline 25 & 17 & $\mathrm{M}$ & LK & 14.3 & 39.2 & 24.9 & 174.1 & 56.7 & 81.6 & 43.9 & 80.1 \\
\hline 26 & 32 & F & RK & 24.3 & 47.1 & 22.8 & 93.8 & 72.9 & 95.7 & 31.3 & 87.9 \\
\hline 27 & 22 & M & LK & 13.8 & 38.2 & 24.4 & 176.8 & 61.3 & 85.7 & 39.8 & 70.6 \\
\hline 28 & 64 & $\mathrm{~F}$ & RK & 25.9 & 62.1 & 36.2 & 139.8 & 95.0 & 131.2 & 38.1 & 75.9 \\
\hline 29 & 35 & M & RK & 26 & 39.3 & 13.3 & 51.2 & 99.1 & 112.4 & 13.4 & 68.4 \\
\hline 30 & 57 & M & LK & 12.9 & 36.2 & 23.3 & 180.6 & 64.0 & 87.3 & 36.4 & 82.8 \\
\hline 31 & 24 & M & RK & 16.2 & 41.7 & 25.5 & 157.4 & 58.8 & 84.3 & 43.4 & 81.9 \\
\hline 32 & 64 & $\mathrm{M}$ & RK & 18.8 & 48.2 & 29.4 & 156.4 & 64.7 & 94.1 & 45.4 & 92.1 \\
\hline 33 & 31 & M & RK & 15.2 & 46.3 & 31.1 & 204.6 & 66.7 & 97.8 & 46.6 & 103.4 \\
\hline 34 & 54 & M & RK & 23.15 & 45.5 & 22.4 & 96.5 & 63.6 & 85.9 & 35.2 & 90.3 \\
\hline
\end{tabular}

DRF showed a mean value of 23.0 (SD \pm 7.8). Percentage increase in the DRF showed a mean value of 116.9 $(\mathrm{SD} \pm 84.2)$. A correlation of 0.93 was observed when the total GFR computed by this method was compared with the eGFR values in this group.

There was a statistically significant increase in the GFR and DRF values as calculated from anterior data setin ectopic kidneys of normal and reduced function ( $p<0.03$ ). Of the23 patients with ectopic kidney GFR value less than $35 \mathrm{ml} / \mathrm{min}$, one patient had an obstructive pattern and was lost to follow up. Again, the anterior renogram in three patients with crossed fused ectopic kidneys and three patients with solitary pelvic kidney also showed higher values of GFR from the anterior data sets. Anterior renogram study was missed in five patients 
Table 3. Increase in GFR of ectopic kidney and total GFR and comparison with eGFR in patients with GFR less than 35 $\mathrm{ml} / \mathrm{min}$ of the ectopic kidney.

\begin{tabular}{|c|c|c|c|c|c|c|c|c|c|c|c|}
\hline Sl. No. & Age & Sex & $\begin{array}{l}\text { Ectopic } \\
\text { Kidney }\end{array}$ & $\begin{array}{c}\text { GFR of } \\
\text { ectopic } \\
\text { kidney from } \\
\text { posterior } \\
\text { dataset } \\
(\mathrm{ml} / \mathrm{min})\end{array}$ & $\begin{array}{c}\text { GFR of } \\
\text { ectopic } \\
\text { kidney from } \\
\text { anterior } \\
\text { dataset } \\
\text { (ml/min) }\end{array}$ & $\begin{array}{l}\text { Difference } \\
\text { in GFR of } \\
\text { ectopic } \\
\text { kidney } \\
(\mathrm{ml} / \mathrm{min})\end{array}$ & $\begin{array}{l}\text { \% Increase } \\
\text { in GFR of } \\
\text { ectopic } \\
\text { kidney }\end{array}$ & $\begin{array}{c}\text { Total GFR } \\
\text { with GFR of } \\
\text { ectopic kidney } \\
\text { form posterior } \\
\text { dataset } \\
(\mathrm{ml} / \mathrm{min})\end{array}$ & $\begin{array}{l}\text { Total GFR } \\
\text { with GFR of } \\
\text { ectopic kidney } \\
\text { form anterior } \\
\text { dataset } \\
\text { (ml/min) }\end{array}$ & $\begin{array}{l}\text { \%Increase in } \\
\text { total GFR with } \\
\text { GFR of ectopic } \\
\text { kidney form } \\
\text { anterior dataset }\end{array}$ & $\begin{array}{c}\text { eGFR } \\
\text { (ml/min) }\end{array}$ \\
\hline 1 & 74 & $\mathrm{M}$ & LK & 2.83 & 10.3 & 7.5 & 264.0 & 15.1 & 22.6 & 49.4 & 41.1 \\
\hline 2 & 53 & $\mathrm{~F}$ & RK & 7.1 & 12.1 & 5.0 & 70.4 & 19.6 & 24.6 & 25.5 & 47.3 \\
\hline 3 & 58 & M & RK & 9.9 & 18.6 & 8.7 & 87.9 & 24.5 & 33.2 & 35.5 & 40.3 \\
\hline 4 & 52 & M & RK & 7.1 & 19.2 & 12.1 & 170.4 & 33.3 & 45.4 & 36.3 & 59.6 \\
\hline 5 & 37 & $\mathrm{M}$ & RK & 4.7 & 20.1 & 15.4 & 327.7 & 21.6 & 37.0 & 71.3 & 46.6 \\
\hline 6 & 59 & $\mathrm{M}$ & LK & 5.6 & 20.3 & 14.7 & 262.5 & 29.1 & 43.8 & 50.5 & 49.4 \\
\hline 7 & 48 & $\mathrm{M}$ & RK & 11 & 21.2 & 10.2 & 92.7 & 31.3 & 41.5 & 32.6 & 50.4 \\
\hline 8 & 65 & $\mathrm{M}$ & LK & 9.8 & 21.4 & 11.6 & 118.4 & 52.3 & 63.9 & 22.2 & 66.1 \\
\hline 9 & 51 & $\mathrm{M}$ & RK & 6.9 & 22.3 & 15.4 & 223.2 & 31.4 & 46.8 & 49.0 & 53.5 \\
\hline 10 & 49 & $\mathrm{M}$ & RK & 7.9 & 22.7 & 14.8 & 187.3 & 18.9 & 33.7 & 78.3 & 38.7 \\
\hline 11 & 49 & $\mathrm{M}$ & RK & 4.3 & 23.1 & 18.8 & 437.2 & 24.6 & 43.4 & 76.5 & 54.5 \\
\hline 12 & 52 & $\mathrm{~F}$ & LK & 10.4 & 23.4 & 13.0 & 125.0 & 32.9 & 45.9 & 39.5 & 53.6 \\
\hline 13 & 45 & $\mathrm{M}$ & LK & 10.7 & 23.7 & 13.0 & 121.5 & 23.4 & 36.4 & 55.6 & 35.1 \\
\hline 14 & 27 & $\mathrm{M}$ & RK & 12.1 & 27.2 & 15.1 & 124.8 & 51.2 & 66.3 & 29.5 & 51.9 \\
\hline 15 & 46 & $\mathrm{M}$ & LK & 7.3 & 29.6 & 22.3 & 305.5 & 32.4 & 54.7 & 68.8 & 51.2 \\
\hline 16 & 47 & $\mathrm{~F}$ & RK & 8.9 & 29.6 & 20.7 & 232.6 & 48.8 & 69.5 & 42.4 & 66.4 \\
\hline 17 & 53 & $\mathrm{~F}$ & RK & 11 & 31.6 & 20.6 & 187.3 & 45.5 & 66.1 & 45.3 & 60.8 \\
\hline 18 & 42 & $\mathrm{M}$ & RK & 16.1 & 31.7 & 15.6 & 96.9 & 48.6 & 64.2 & 32.1 & 64.8 \\
\hline 19 & 63 & M & RK & 14.1 & 31.9 & 17.8 & 126.2 & 59.4 & 77.2 & 30.0 & 69.4 \\
\hline 20 & 16 & $\mathrm{M}$ & RK & 16.1 & 32.5 & 16.4 & 101.9 & 96.7 & 113.1 & 17.0 & 114.4 \\
\hline 21 & 49 & $\mathrm{M}$ & LK & 7.3 & 33.7 & 26.4 & 361.6 & 32.4 & 58.8 & 81.5 & 50.9 \\
\hline
\end{tabular}

with ectopic kidney who were not suspected to have an ectopic kidney before the renogram was done. In another five patients with suspected ectopic kidney, anterior renogram excluded the possibility of ectopic kidney.

\section{Discussion}

Numerous methods are available to compute total GFR of kidneys [17]-[23], some of which involve imaging. Whichever protocol is used, it is imperative that the technique is meticulous and that the protocol is followed correctly [24]-[26]. Multiple blood sample techniques and subsequently single blood sample technique were developed to improve the accuracy of the computed GFR [27]. The Gates method used to compute GFR in scintigraphy does not require blood sampling. Instead, it uses posterior image data set acquired on a gamma camera. The Gates method is most commonly used to compute the GFR in DTPA renogram. In Gates method the percentage renal uptake (\%RU) of ${ }^{99 \mathrm{~m}}$ Tc DTPA is computed first [5].

$$
\% R U=\frac{\frac{\text { RK cts }- \text { bkgd }}{\mathrm{e}^{-\mu \mathrm{x}}}+\frac{\text { LK cts }- \text { bkgd }}{\mathrm{e}^{-\mu \mathrm{x}}}}{\text { (Pre injection cts }- \text { post injection cts })}
$$

(RK cts = right kidney counts, bkgd = background counts, LK cts = left kidney counts and $\mu=$ linear attenuation co-efficient of ${ }^{99 \mathrm{~m}}$ Tc in soft tissue which is equal to 0.153 and xis kidney depth given by Equations (4)-(6))

$$
\begin{aligned}
& \text { Depth of Right Kidney }=13.3 \cdot y+0.7 \\
& \text { Depth of Left Kidney }=13.2 \cdot y+0.7
\end{aligned}
$$

where 
Table 4. Increasein DRF in patients with GFR of ectopic kidney greater than $35 \mathrm{ml} / \mathrm{min}$ from anterior renogram.

\begin{tabular}{|c|c|c|c|c|c|c|c|c|}
\hline Sl. No. & Age & Sex & $\begin{array}{l}\text { Ectopic } \\
\text { Kidney }\end{array}$ & $\begin{array}{l}\text { DRF of Ectopic Kidney } \\
\text { from posterior renogram } \\
\text { (\%) }\end{array}$ & $\begin{array}{c}\text { DRF of Ectopic Kidney } \\
\text { from anterior renogram } \\
\text { (\%) }\end{array}$ & $\begin{array}{l}\text { Difference } \\
\text { in DRF }\end{array}$ & $\begin{array}{l}\text { \% Increase } \\
\text { in DRF }\end{array}$ & $\begin{array}{l}\text { DRF of the ectopic } \\
\text { kidney from Geometric } \\
\text { mean image (\%) }\end{array}$ \\
\hline 1 & 22 & $\mathrm{M}$ & LK & 23.3 & 47.2 & 23.9 & 102.5 & 36.5 \\
\hline 2 & 34 & $\mathrm{M}$ & LK & 22.7 & 41.8 & 19.0 & 83.7 & 40.6 \\
\hline 3 & 40 & $\mathrm{M}$ & LK & 19.4 & 45.9 & 26.6 & 137.3 & 36.7 \\
\hline 4 & 58 & $\mathrm{~F}$ & LK & 24.4 & 39.4 & 15.1 & 61.9 & 35.6 \\
\hline 5 & 35 & $\mathrm{M}$ & LK & 26.3 & 40.5 & 14.2 & 53.8 & 38.5 \\
\hline 6 & 17 & $\mathrm{M}$ & $\mathrm{RK}$ & 38.2 & 49.2 & 11.0 & 28.7 & 45.6 \\
\hline 7 & 33 & $\mathrm{~F}$ & RK & 19.6 & 47.2 & 27.7 & 141.4 & 46.1 \\
\hline 8 & 48 & $\mathrm{M}$ & LK & 27.8 & 51.4 & 23.5 & 84.5 & 45.8 \\
\hline 9 & 24 & $\mathrm{~F}$ & LK & 31.5 & 51.2 & 19.7 & 62.4 & 42.7 \\
\hline 10 & 34 & $\mathrm{M}$ & LK & 42.0 & 52.3 & 10.3 & 24.4 & 46.3 \\
\hline 11 & 49 & $\mathrm{M}$ & LK & 29.5 & 51.3 & 21.8 & 73.9 & 47.3 \\
\hline 12 & 36 & $\mathrm{M}$ & LK & 37.5 & 53.5 & 16.0 & 42.6 & 43.5 \\
\hline 13 & 29 & $\mathrm{~F}$ & LK & 30.7 & 50.6 & 19.9 & 64.6 & 52.1 \\
\hline 14 & 18 & $\mathrm{~F}$ & LK & 25.1 & 48.1 & 23.0 & 91.4 & 49.6 \\
\hline 15 & 21 & $\mathrm{~F}$ & LK & 22.3 & 44.8 & 22.6 & 101.4 & 46.3 \\
\hline 16 & 35 & $\mathrm{~F}$ & RK & 35.9 & 49.9 & 13.9 & 38.8 & 45.8 \\
\hline 17 & 37 & $\mathrm{M}$ & RK & 36.3 & 52.6 & 16.3 & 44.8 & 49.3 \\
\hline 18 & 27 & $\mathrm{~F}$ & RK & 27.7 & 51.1 & 23.4 & 84.7 & 49.6 \\
\hline 19 & 23 & $\mathrm{~F}$ & LK & 32.0 & 51.7 & 19.7 & 61.3 & 47.8 \\
\hline 20 & 42 & $\mathrm{M}$ & LK & 33.5 & 47.5 & 14.0 & 41.8 & 48.9 \\
\hline 21 & 19 & $\mathrm{M}$ & LK & 20.7 & 49.8 & 29.0 & 140.0 & 49.2 \\
\hline 22 & 7 & $\mathrm{M}$ & LK & 39.0 & 47.0 & 8.0 & 20.5 & 45.3 \\
\hline 23 & 32 & $\mathrm{~F}$ & $\mathrm{RK}$ & 22.2 & 49.5 & 27.2 & 122.5 & 46.9 \\
\hline 24 & 25 & $\mathrm{~F}$ & RK & 27.6 & 49.4 & 21.9 & 79.4 & 48.2 \\
\hline 25 & 17 & $\mathrm{M}$ & LK & 25.2 & 48.0 & 22.8 & 90.5 & 49.3 \\
\hline 26 & 32 & $\mathrm{~F}$ & RK & 33.3 & 49.2 & 15.9 & 47.6 & 51.2 \\
\hline 27 & 22 & $\mathrm{M}$ & LK & 22.5 & 44.6 & 22.1 & 98.0 & 42.3 \\
\hline 28 & 64 & $\mathrm{~F}$ & RK & 27.3 & 47.3 & 20.1 & 73.6 & 46.9 \\
\hline 29 & 35 & $\mathrm{M}$ & RK & 26.2 & 35.0 & 8.7 & 33.3 & 36.9 \\
\hline 30 & 57 & $\mathrm{M}$ & LK & 20.2 & 41.5 & 21.3 & 105.7 & 43.9 \\
\hline 31 & 24 & $\mathrm{M}$ & RK & 27.6 & 49.5 & 21.9 & 79.5 & 45.9 \\
\hline 32 & 64 & $\mathrm{M}$ & $\mathrm{RK}$ & 29.1 & 51.2 & 22.2 & 76.3 & 48.3 \\
\hline 33 & 31 & $\mathrm{M}$ & RK & 22.8 & 47.3 & 24.6 & 107.7 & 39.5 \\
\hline 34 & 54 & $\mathrm{M}$ & RK & 36.4 & 53.0 & 16.6 & 45.5 & 45.6 \\
\hline
\end{tabular}

$$
\mathrm{y}=\frac{\text { Weight in } \mathrm{Kg}}{\text { Height in } \mathrm{cm}}
$$

The total GFR in $\mathrm{ml} / \mathrm{min}$ is computed as follows.

$$
\mathrm{GFR}=\mathrm{RU} \cdot(9.8127)-(6.82519)
$$

GFR of each kidney is computed by proportionately dividing the total GFR value with the DRF of each kidney that is already computed [9]. From Equations (3) to (7), it is evident that the depth of the kidneys is an important factor in the computation of GFR by Gates method.

Sum of the DRF values for normal kidney from posterior data set and for the ectopic kidney from anterior data set is not equal to 100 percent in all the patients. This pitfall is overcome by computing the DRF values as 
Table 5. Increase in DRF in patients with GFR of ectopic kidney less than $35 \mathrm{ml} / \mathrm{min}$ from anterior renogram.

\begin{tabular}{|c|c|c|c|c|c|c|c|c|}
\hline Sl. No. & Age & Sex & $\begin{array}{l}\text { Ectopic } \\
\text { Kidney }\end{array}$ & $\begin{array}{l}\text { DRF of Ectopic Kidney } \\
\text { from posterior renogram } \\
(\%)\end{array}$ & $\begin{array}{l}\text { DRF of Ectopic Kidney } \\
\text { from anterior renogram } \\
(\%)\end{array}$ & $\begin{array}{l}\text { Difference } \\
\text { in DRF }\end{array}$ & $\begin{array}{c}\text { \% Increase } \\
\text { in DRF }\end{array}$ & $\begin{array}{l}\text { DRF of the ectopic } \\
\text { kidney from Geometric } \\
\text { mean image (\%) }\end{array}$ \\
\hline 1 & 74 & M & LK & 6.6 & 45.6 & 38.9 & 586.5 & 39.6 \\
\hline 2 & 53 & $\mathrm{~F}$ & RK & 36.2 & 49.2 & 13.0 & 35.8 & 42.9 \\
\hline 3 & 58 & M & RK & 40.4 & 56.0 & 15.6 & 38.6 & 45.6 \\
\hline 4 & 52 & M & RK & 21.3 & 42.3 & 21.0 & 98.3 & 41.7 \\
\hline 5 & 37 & M & RK & 21.8 & 54.3 & 32.6 & 149.7 & 52.3 \\
\hline 6 & 59 & M & LK & 19.2 & 46.3 & 27.1 & 140.8 & 45.3 \\
\hline 7 & 48 & M & RK & 35.1 & 51.1 & 15.9 & 45.4 & 47.2 \\
\hline 8 & 65 & M & LK & 18.7 & 33.5 & 14.8 & 78.7 & 36.6 \\
\hline 9 & 51 & $\mathrm{M}$ & RK & 22.0 & 47.6 & 25.7 & 116.8 & 45.9 \\
\hline 10 & 49 & M & RK & 41.8 & 67.3 & 25.6 & 61.2 & 62.5 \\
\hline 11 & 49 & $\mathrm{M}$ & RK & 17.5 & 53.2 & 35.8 & 204.4 & 49.7 \\
\hline 12 & 52 & $\mathrm{~F}$ & LK & 31.6 & 51.0 & 19.4 & 61.3 & 52.3 \\
\hline 13 & 45 & M & LK & 45.7 & 65.1 & 19.4 & 42.4 & 62.9 \\
\hline 14 & 27 & M & RK & 23.6 & 41.0 & 17.4 & 73.6 & 44.7 \\
\hline 15 & 46 & M & LK & 22.5 & 54.1 & 31.6 & 140.2 & 51.2 \\
\hline 16 & 47 & F & RK & 18.3 & 42.6 & 24.3 & 132.7 & 40.9 \\
\hline 17 & 53 & $\mathrm{~F}$ & RK & 24.2 & 47.8 & 23.6 & 97.7 & 45.6 \\
\hline 18 & 42 & M & RK & 33.1 & 49.4 & 16.2 & 49.1 & 43.7 \\
\hline 19 & 63 & M & RK & 23.7 & 41.3 & 17.6 & 74.1 & 42.5 \\
\hline 20 & 16 & M & RK & 16.6 & 28.7 & 12.1 & 72.6 & 32.3 \\
\hline 21 & 49 & M & LK & 22.5 & 57.3 & 34.8 & 154.4 & 52.8 \\
\hline
\end{tabular}

Table 6. Increase in GFR and DRF values for patients with GFR of the ectopic kidney $>35 \mathrm{ml} / \mathrm{min}$ from anterior data set.

\begin{tabular}{cccccc}
\hline & $\begin{array}{c}\text { Increase in GFR of ectopic } \\
\text { kidney }\end{array}$ & $\begin{array}{c}\text { \%Increase in GFR of ectopic } \\
\text { kidney }\end{array}$ & $\begin{array}{c}\text { \%Increase in Total GFR } \\
\text { Increase in DRF }\end{array}$ & \% Increase in DRF \\
\hline Mean & 24.4 & 144.0 & 37.8 & 19.5 & 74.9 \\
SD & 6.4 & 61.7 & 10.8 & 5.3 & 32.6 \\
Min & 13.3 & 38.7 & 13.4 & 8.0 & 20.5 \\
Max & 43.9 & 278.8 & 131.2 & 29.0 & 141.4 \\
p & 0.006 & $<0.001$ & $<0.001$ & $<0.001$ & $<0.001$ \\
\hline
\end{tabular}

Table 7. Increase in GFR and DRF values for patients $(n=21)$ with GFR of the ectopic kidney $<35 \mathrm{ml} / \mathrm{min}$ from anterior data set.

\begin{tabular}{cccccc}
\hline & $\begin{array}{c}\text { Increase in GFR of ectopic } \\
\text { kidney }\end{array}$ & $\begin{array}{c}\text { \% Increase in GFR of ectopic } \\
\text { kidney }\end{array}$ & \% Increase in Total GFR & Increase in DRF & \% Increase in DRF \\
\hline Mean & 15.0 & 191.7 & 46.1 & 23.0 & 116.9 \\
SD & 5.0 & 100.0 & 18.9 & 7.8 & 84.2 \\
Min & 5.0 & 70.4 & 17.0 & 12.1 & 35.8 \\
Max & 26.4 & 437.2 & 81.5 & 38.9 & 586.5 \\
p & $<0.001$ & $<0.001$ & 0.004 & 0.003 & 0.003 \\
\hline
\end{tabular}

shown in Equations (1) and (2).Anterior and posterior images that are acquired simultaneously are needed to compute the geometric mean images. This is not possible in the single headed gamma camera. Equations (1) and (2) can be applied to the images that are obtained from anterior and posterior images obtained in two separate studies. Hence this method can be applied in studies done in single headed gamma camera.

Out of the 55 patients studied, 34 (61.8\%) showed a lower GFR value from posterior data set and a normal 
GFR value from anterior data set, and 21 (38.2\%) showed reduced GFR from both datasets. However, in the latter group too, the GFR calculated from the anterior dataset remained higher. Therefore, in 34 patients, calculation of GFR by anterior dataset established normal functional status of the ectopic kidney, which would otherwise have been reported as poorly functioning. Twenty one patients $(38.2 \%)$ showed GFR values $<35 \mathrm{ml} / \mathrm{min}$ even from the anterior data set, confirming the poor functional status of the ectopic kidney. The total GFR as calculated by the dual dataset (anterior and posterior) was compared to the eGFR; there was a better correlation in patients with total GFR $<35 \mathrm{ml} / \mathrm{min}$ than in the patients with total GFR $>35 \mathrm{ml} / \mathrm{min}$.

\section{Conclusion}

There is underestimation of GFR and DRF of an anteriorly placed ectopic kidney in the conventional posterior renogram. Anterior renogram data set provides improved accuracy of GFR estimation of an ectopic kidney. A modified method to compute the DRF using the anterior and posterior renogram datasets also shows higher DRF values for the ectopic kidneys. Renogram analyses done by Gate's method with anterior and posterior datasets improve the accuracy of the GFR and DRF values and help to differentiate a normally functioning ectopic kidney from a poorly functioning one.

\section{Acknowledgements}

The authors are grateful to the Chief, TMH for all the support and encouragement in carrying out this study at Tata Main Hospital.

\section{References}

[1] Ziessman, H.A., O’Malley, J.P. and Thrall, J.H. (2006) Genitourinary System. “Nuclear Medicine-The Requisites”. 3rd Edition, Elseiver Mosby, Philadelphia, 215-224.

[2] O’ Reilly, P.H. (1992) Diuresis Renography: Recent Advances and Recommended Protocols, British Journal of Urology, 69, 113-120. http://dx.doi.org/10.1111/j.1464-410X.1992.tb15479.x

[3] Shulkin, B.L., Mandell, G.A., Cooper, J.A., Leonard, J.C., et al. (2008) Procedure Guideline for Diuretic Renography in Children 3.0. Journal of Nuclear Medicine Technology, 36, 162-168. http://dx.doi.org/10.2967/jnmt.108.056622

[4] Blaufox, M.D., Aurell, M. and Bubeck, B. (1996) Report of Radionuclides in Nephrology Committee on Renal Clearance, Journal of Nuclear Medicine, 37, 1883-1890.

[5] Gates, G.F. (1982) Glomerular Filtration Rate: Estimation from Fractional Accumulation of 99mTc DTPA. American Journal of Roentgenology, 565-570.

[6] Gruenewald, S.M., Collins, L.T. and Fawdry, R.M. (1985) Kidney Depth Measurement and Its Influence on Quantitation of Function from Gamma Camera Renography. Clinical Nuclear Medicine, 6, 398-401. http://dx.doi.org/10.1097/00003072-198506000-00002

[7] Awedh, M., Kouris, K., et al. (1990) Factors Affectring the Gates’ Measurement of Glomerular Filtration Rate. American Journal of Physiologic Imaging, 1, 36-41.

[8] Graneurus, G. and Moomen, M. (1991) Effects of Extra Renal Background Subtraction and Kidney Depth Correction in the Measurement of GFR by Gamma Camera Renography. Nuclear Medicine Communications, 12, 519-527. http://dx.doi.org/10.1097/00006231-199106000-00006

[9] Piepsz, A., Kinthaert, J., Tondeur, M., et al. (1996) The Robustness of the Patlak-Rutland Slope for the Determination of Split Renal Function. Nuclear Medicine Communications, 14, 817-822. http://dx.doi.org/10.1097/00006231-199609000-00014

[10] ACR-SPR Practice Guideline for the Performance of Renal Scintigraphy, Resolution 51, Revised 2013: 1-7. http://www.acr.org/guidelines

[11] Piepsz, A., Blaufox, M.D., Gordon, I., et al. (1999) Consensus on Renal Cortical Scintigraphy in Children with Urinary Tract Infection. Seminars in Nuclear Medicine, 29, 160-174. http://dx.doi.org/10.1016/S0001-2998(99)80006-3

[12] Lythgoe, M.F., Gradwell, M.J., Evans, K. and Gordon, I. (1998) Estimation and Relevance of Depth Correction in Paediatric Renal Studies. European Journal of Nuclear Medicine, 25, 115-119. http://dx.doi.org/10.1007/s002590050202

[13] Dostbil, Z., Pembegül, N., Küçüköner, M., et al. (2011) Comparison of Split Renal Function Measured by 99mTc-DTPA, 99mTc-MAG3 and 99mTc-DMSA Renal Scintigraphies in Paediatric Age Groups. Clinical Psychology Review, 20-25. 
[14] Lesley, A.S., Coresh, J., Greene, T. and Andrew, S.L. (2006) Assessing Kidney Function-Measuredand Estimated Glomerular Filtration Rate. The New England Journal of Medicine, 354, 2475-2483.

[15] Zhao, X., Shao, Y., Wang, Y., et al. (2012) New Normal Values Not Related to Age and Sex, of Glomerular Filtration Rate by 99mTc-DTPA Renal Dynamic Imaging, for the Evaluation of Living Kidney Graft Donors. Hellenic Journal of Nuclear Medicine, 210-214.

[16] Botev, R., Mallie, J.-P., et al. (2009) Estimating Glomerular Filtration Rate: Cockcroft-Gault and Modifying Diet in Renal Disease Formulas Compared to Inulin Clearance. Clinical Journal of the American Society of Nephrology, 4, 899-906. http://dx.doi.org/10.2215/CJN.05371008

[17] Russell, C.D., Bischoff, P.G., Kontzen, F., Rowell, K.L., Yester, M.V., Lloyd, L.K., et al. (1985) Measurement of Glomerular Filtration Rate Using 99mTc-DTPA and the Gamma Camera: A Comparison of Methods. European Journal of Nuclear Medicine, 10, 519-521.

[18] Fawdry, R.M., Grueneward, S.M., Collins, L.T. and Roberts, A.J. (1985) Comparative Assessment of Techniques for Estimation of Glomerular Filtration Rate with Tc-99m-DTPA. European Journal of Nuclear Medicine, 11, 7-12. http://dx.doi.org/10.1007/BF00440953

[19] Mulligan, J.S., Blue, P.W. and Hasbargen, J.A. (1990) Methods for Measuring GFR with Technetium-99m-DTPA: An Analysis of Several Common Methods. Journal of Nuclear Medicine, 31, 1211-1219.

[20] Goates, J.J., Morton, K.A., Whooten, W.W., Greenberg, H.E., Datz, F.L., Handy, J.E., et al. (1990) Comparison of Methods for Calculating Glomerular Filtration Rate: Technetium-99m-DTPA Scintigraphic Analysis, Protein-Free and Whole-Plasma Clearance of Technetium-99m-DTPA and Iodine-125-Iothalamate Clearance. Journal of Nuclear Medicine, 31, 424-429.

[21] Duran, E., Prigent, A. and Gaillard, J. (1997) Comparison between 9 Methods for Estimation of Glomerular Filtration Rate (GFR) with Simultaneous Injection of 51Cr-EDTA and 99mTc-DTPA. In: Taylor Jr., A., Nally, J. and Thomsen, H., Eds., Radionuclides in Nephrourology, Reston, 112-120.

[22] Itoh, K., Tsushima, S., Tsukamoto, E. and Tamaki, N. (2000) Reappraisal of Single-Sample and Gamma Camera Methods for Determination of the Glomerular Filtration Rate with 99mTc-DTPA. Annals of Nuclear Medicine, 14, 143150. http://dx.doi.org/10.1007/BF02987852

[23] Russell, C.D., Bischoff, P.G., Kontzen, F.N., Rowell, K.L., Yester, M.V., Lloyd, L.K., et al. (1985) Measurement of Glomerular Filtration Rate: Single Injection Plasma Clearance Method without Urine Collection. Journal of Nuclear Medicine, 26, 1243-1247.

[24] De Santo, N.G., Anastasio, P., Cirillo, M., Santoro, D., Spitali, L., Mansi, L., et al. (1999) Measurement of Glomerular Filtration Rate by the 99mTc-DTPA Renogram Is Less Precise than Measured and Predicted Creatinine Clearance. Nephron, 81, 136-140. http://dx.doi.org/10.1159/000045268

[25] Virga, G., La Milia, V., Russo, R., Bonfante, L., Cara, M. and Nordio, M. (2010) Comparison between CreatinineBased Equations for Estimating Total Creatinine Clearance in Peritoneal Dialysis: A Multicentre Study. Nephrology Dialysis Transplantation, 25, 262-269. http://dx.doi.org/10.1093/ndt/gfp391

[26] Aydin, F., Güngör, F., Cengiz, A.K., Tuncer, M., Mahsereci, E., Ozdem, S., et al. (2008) Comparison of Glomerular Filtration Rate Measurements with the Two Plasma Sample and Single Plasma Sample, Gamma Camera Gates, Creatinine Clearance, and Prediction Equation Methods in Potential Kidney Donors with Normal Renal Function. Nuclear Medicine Communications, 29, 157-165. http://dx.doi.org/10.1097/MNM.0b013e3282f1bbde

[27] Prigent, A., Cosgriff, P., et al. (1999) Consensus Report on Quality Control of Quantitative Measurements of Renal Function Obtained from Renogram. International Consensus Committee from the Scientific Committee of Radionuclides in Nephrourology. Seminars in Nuclear Medicine, 29, 146-159.

http://dx.doi.org/10.1016/S0001-2998(99)80005-1 